\title{
GIS Based Approach for Vulnerability Assessment of the Karnataka Coast, India
}

\author{
Akshaya Beluru Jana and Arkal Vittal Hegde \\ Department of Applied Mechanics and Hydraulics, NITK, Surathkal, Mangaluru 575025, India \\ Correspondence should be addressed to Akshaya Beluru Jana; aksh.jana@gmail.com \\ Received 16 November 2015; Accepted 17 April 2016 \\ Academic Editor: Kirk Hatfield
}

Copyright (C) 2016 A. Beluru Jana and A. V. Hegde. This is an open access article distributed under the Creative Commons Attribution License, which permits unrestricted use, distribution, and reproduction in any medium, provided the original work is properly cited.

\begin{abstract}
The coastal zones are highly resourceful and dynamic. In recent times, increased events of tropical cyclones and the devastating impact of the December 2004 tsunami have brought forth the importance of assessing the vulnerability of the coast to hazardinduced flooding and inundation in coastal areas. This study intends to develop coastal vulnerability index (CVI) for the administrative units, known as talukas of the Karnataka state. Seven physical and geologic risk variables characterizing the vulnerability of the coast, including rate of relative sea level change, historical shoreline change, coastal slope, coastal regional elevation, mean tidal range, and significant wave height derived using conventional and remotely sensed data, along with one socioeconomic parameter "population," were used in the study. A total of $298 \mathrm{~km}$ of shoreline are ranked in the study. It was observed that about $68.65 \mathrm{~km}$ of the shoreline is under very high vulnerable category and $79.26 \mathrm{~km}$ of shoreline is under high vulnerable category. Of the remaining shoreline, $59.14 \mathrm{~km}$ and $91.04 \mathrm{~km}$ are of moderate and low vulnerable categories, respectively.
\end{abstract}

\section{Introduction}

Significant changes in environmental and physical processes have been observed in coastal areas as a result of intensive urbanization and tourism [1]. It has been estimated that human population of around 600 million would inhabit coastal flood plains by the year 2100 [2]. Additionally, coastal ecosystem is being subjected to frequent events of hazards such as storms, associated waves and storm surges, tsunamis, river flooding, shoreline erosion, and the influx of biohazards like algal blooms and pollutants [3]. Further, global climate change and the threat of accelerated sea level rise have aggravated the already existing high risks of storm surges, severe waves, and tsunamis [3].

Indian main land has a coastline of about $5,400 \mathrm{~km}$ and around 250 million people live within $50 \mathrm{~km}$ of the coastline of India [4]. In spite of the various policies and regulatory frameworks, India's coastal and marine ecosystems are under threat due to multiple stresses [5]. The event of December 2004 tsunami brought about importance for scientific study of the natural hazards and coastal processes of the Indian coast [6].
Mitigating the effects of potential disasters and having the appropriate infrastructure in place for the response require a detailed knowledge about vulnerability of the places to a wide range of hazards [7]. Since vulnerability may be associated with natural or social hazards or sometimes a combination of both, various dimensions involving a hazard must be taken into account to effectively carry out a vulnerability assessment [8]. Various coastal vulnerability assessment methods were developed for managing the coasts which include inundation maps, common methodology (IPCC), and computer aided models. Coastal vulnerability index (CVI) developed by Thieler and Hammar-Klose [9-11] is one of the accepted and most commonly used indices for calculating the vulnerability towards the coastal erosion and sea level rise. The majority of the studies using CVI have categorized the vulnerability of different coastal environments relatively, using basic information on coastal geomorphology, rate of sea level rise, past shoreline evolution, coastal slope, mean tidal range, and mean wave height and acknowledged that inclusion of demographic and economic variables may result in a useful and more comprehensive index [12]. Subsequent studies did 

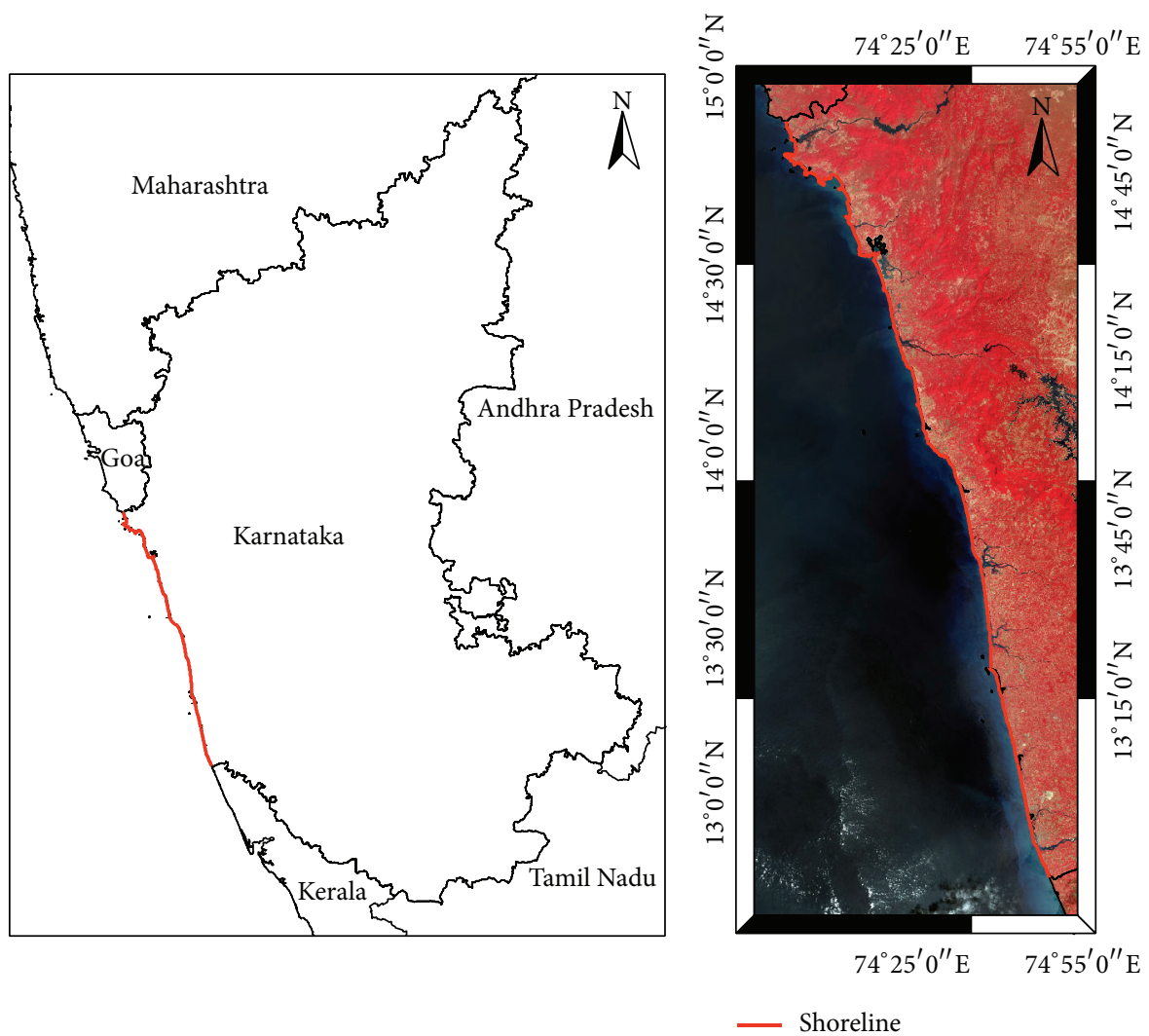

FIGURE 1: Study area.

consider the socioeconomic variables for their assessments [13-15]. Researchers adopted techniques of remote sensing and Geographic Information System (GIS) to assemble, assess, and display data about various vulnerability variables and to calculate CVI [6, 16-18].

Geographic Information System (GIS) handles spatial information by linking location with its attribute information. GIS has functions and tools required to efficiently capture, store, analyze, and display the information about places and things. The preparation of data and mapping the spatial relationships between natural hazard phenomena and the elements under threat require the use of GIS. The techniques of remote sensing, GIS, and GPS have been proven to provide extremely valuable data for analysis of the scenario and develop management action plans. Studies showed that satellite remote sensing offered high temporal resolution for monitoring of land-use change at lower costs than those associated with the use of traditional methods $[19,20]$. The advantages of repetitive coverage and synoptic view of the region of interest from various earth observation satellites have assisted in generation of databases on various aspects of the coastal and marine environment [21].

Vulnerabilities associated with the various coastal states of India are being studied in recent times [6, 22-27]. From the literatures it was noticed that previously Hegde and Reju [18] and Dwarakish et al. [28] had assessed the vulnerability for the smaller parts of the Karnataka Coast. Both the studies were limited to a smaller stretch of coast, Dwarakish et al.
[28] did not include socioeconomic variables for their study, and Hegde and Reju [18] used coastal slope as a supplement to regional elevation. Though Appelquist and Balstrøm [29] had applied the concept of Coastal Hazard Wheel (CHW) framework for the complete coast of the Karnataka, their framework had lacuna of noninclusion of the socioeconomic variables for the assessment. The present study attempts to assess vulnerability of the coastal Karnataka for various hazards by combining physical, geological, and socioeconomical variables using techniques of remote sensing and GIS.

\section{Study Area}

The study area (Figure 1) is the coast of Karnataka state extending from Talpadi to Sadashivgad between longitude $74^{\circ} 5^{\prime} 22.09^{\prime \prime} \mathrm{E}$ and $74^{\circ} 51^{\prime} 53.75^{\prime \prime} \mathrm{E}$ and latitude $14^{\circ} 53^{\prime} 36.53^{\prime \prime} \mathrm{N}$ and $12^{\circ} 45^{\prime} 02^{\prime \prime} \mathrm{N}$ covering a distance of about $298 \mathrm{~km}$. The coastal Karnataka consists of the entire stretch of Udupi, Dakshina Kannada, and parts of Uttara Kannada districts. The coast is bounded by the Western Ghats in the east and the Arabian Sea on the west and is intercepted with a number of rivers joining the Arabian Sea. Coastal areas near the river mouths along the study area suffer permanent erosion due to natural shifting and migration of the river mouths [30]. The tides are of mixed semidiurnal type and its range increases towards the north of the state [31]. Significant wave height, during the monsoon, has been assessed to be greater than $3 \mathrm{~m}$ [6] and is normally less than $1.5 \mathrm{~m}$ during the rest of 
TABLE 1: List of variables and data source.

\begin{tabular}{lcc}
\hline Variables & Data source & Time period \\
\hline Sea level change rate & PSMSL (http://www.psmsl.org/) & $1976-2004$ \\
Shoreline change rate & Earth Explorer (http://earthexplorer.usgs.gov/) & $1972-2014$ \\
Coastal slope & GEBCO (http://www.gebco.net/) & - \\
Regional elevation & SRTM (http://srtm.csi.cgiar.org/) & - \\
Tidal range & Secondary data & - \\
Significant wave height & Secondary data & - \\
Population & Worldpop (http://www.worldpop.org.uk/) & 2010 \\
\hline
\end{tabular}

the year. Deep-water waves approach the coast from southwestern and north-western directions [6].

The northern part of the study area is geologically composed of Precambrian crystalline gneiss, schist, and granite rocks, fronted by a narrow coastal plain of alluvial or tertiary deposits. In locations where the rock extends to the coastline, coastal cliffs and rocky shores are formed. The coastline has drowned river valleys, estuaries, and many small inlets, which is a typical submergence characteristic [32]. The southern part of study area has extensive straight beaches and estuaries with low estuarine islands and mangroves.

\section{Methodology}

The present study adopts the CVI methodology formulated by Thieler and Hammer-Klose [9-11]. The process results in a classification of coast using simple criteria and yields numerical data that cannot be equated directly with particular physical effects but shows the area's most affected by the hazard. Initially a database of the variables under consideration for the study area was built by compiling data from various sources. Table 1 details the variables and their data sources used in the present study. The data values of variables under consideration were assigned a vulnerability ranking based on value ranges contributing to coastal vulnerability, while the nonnumerical geomorphology variable was ranked qualitatively according to the relative resistance of a given landform to erosion. Later, the key variables were integrated to a single index and categorized based on the relative intensity of risk it imparts to the coast, namely, very low, low, medium, high, and very high. The entire coastline was divided into 8 zones based on administrative boundary of talukas. A grid template of $1.5 \mathrm{~km}$ by $1.5 \mathrm{~km}$ was used to store and analyze data and display the CVI, similar to the procedure adopted by Abuodha and Woodroffe [33]. Each cell of the grid template was assigned with an identification number as shown in Figure 2. The software package ArcGIS 9.3 offers the suitable environment to carry out the process. The variation of each variable within the area was analyzed and suitable risk ratings were awarded for each specific data variable and the coastal vulnerability index was calculated.

In the present study, eight variables were considered for developing the CVI: rate of relative sea level change, historical rate of shoreline change (erosion or accretion), coastal regional elevation, coastal slope, mean tidal range, significant wave height, and socioeconomic data. The importance of each

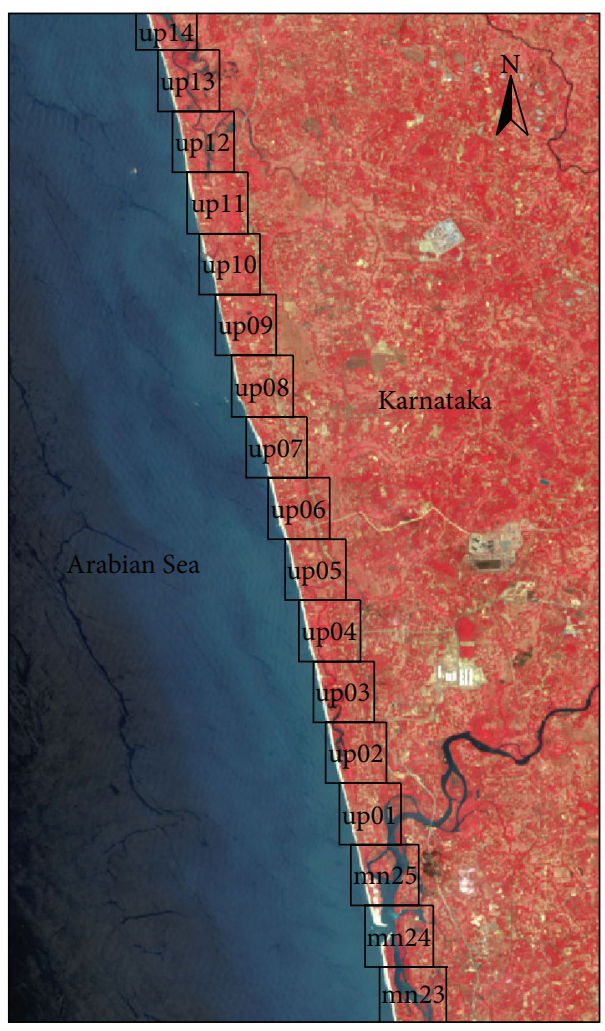

FIGURE 2: Grid template for the study area.

of the considered parameters and the procedure to generate the same for use in assessment of CVI are given in the following section.

3.1. Relative Sea Level Change Rate. Sea level rise shifts the wave action zone to higher elevations due to recession of coast to inland. This recession of shoreline will be greater in mild slope regions [34]. The direct effect of such recession is submergence of coastal land and aggravated events of flooding. Long-term effects can be increased erosion and saltwater intrusion into ground water as the coast adjusts to the new conditions [35]. According to IPCC, every millimeter rise of mean sea level on the coast would result in a shoreline retreat of about $1 \mathrm{~m}$. Mean sea level at the coast is the height of the sea with respect to a local land benchmark, averaged over a long time period. Changes in mean sea level as measured by coastal tide gauges are called relative sea level changes [36]. 
The Permanent Service for Mean Sea Level (PSMSL) data has been used in the study to calculate the relative sea level change rate. The study area consists of two PSMSL tide gauge stations, namely, Mangaluru and Karwar. The monthly mean sea level data from 1976 to 2000 are downloaded for Mangaluru station and from 1970 to 2004 for the Karwar station from the PSMSL website. The monthly mean values of sea level recorded at these stations were plotted, from which a linear best fit line adopting least squares method was computed to calculate the sea level change rate, and risk ratings were assigned. Coast subjected to a high rate of sea level rise was considered as a high vulnerable area and vice versa.

3.2. Shoreline Change Rate. The shoreline change rate is one of the most common measurements used to indicate the dynamics and the hazards of the coast [41]. Coastal shorelines are always subjected to changes due to coastal processes, which are controlled by wave characteristics and the resultant near-shore circulation, sediment characteristics, beach form, and so forth. From the coastal vulnerability point of view, coasts subjected to accretion are considered as less vulnerable areas as they move towards the ocean and result in the addition of land areas, whereas areas of coastal erosion are considered to be more vulnerable because of the resultant loss of individual and public property as well as important natural habitats. It also trims down the distance between coastal population and ocean, thereby increasing the risk of exposure of population to coastal hazards.

Orthorectified satellite images of the study area from the sensors Landsat MSS, ETM+ and OLI-TIRS for the years 1972, 1991, 1998, 2000, 2006, 2012, and 2014 were downloaded from USGS Earth Explorer web tool. The images were projected to the Universal Transverse Mercator (UTM) projection system with WGS-84 datum. Histogram splicing was applied to create a binary image from near infrared band of each image and is classified as unsupervised to form image with complete separation between land and water classes. These classified images were used to extract the shorelines in the form of vector layer using ERDAS Imagine 9.2 and ArcMap 9.3.

The digitized shoreline for the years 1972, 1991, 1998, 2000, 2006, 2012, and 2014 in the vector format was used as the input to the Digital Shoreline Analysis System (DSAS). DSAS computes rate-of-change statistics from multiple historic shoreline positions by using GIS [42]. Transects were cast perpendicular to the baseline at a $100 \mathrm{~m}$ interval all along the shore using DSAS. The crossover of these transects with shoreline along the baseline is then used to calculate the rateof-change statistics. Linear Regression Rate (LRR) method of shoreline change rate estimation was used in this study. LRR uses all the available data to find a line, which has the overall minimum of the squared distance to the known shoreline and is an established method for computing long-term rates of shoreline change [43]. Risk ratings were assigned based on the LRR.

3.3. Coastal Slope. The coastal slope is change in altitude for a unit horizontal distance between any two points on the coast. The degree of steepness or flatness of a coastal region determines the susceptibility of the coast to inundation by
TABLE 2: Tidal range for various zones and their source.

\begin{tabular}{lcc}
\hline Location & Tidal range (m) & Source \\
\hline Karwar, Ankola \& Kumta & 1.58 & Kumar et al. [37] \\
Honnavar & 2.1 & \\
Kundapur \& Bhatkal & 1.9 & Sanil Kumar et al. [38] \\
Udupi (Malpe) & 1.8 & \\
Mangaluru & 1.6 & Dwarakish et al. [28] \\
\hline
\end{tabular}

flooding [44]. Determination of regional coastal slope identifies the relative vulnerability of inundation and potential rapidity of shoreline retreat because low sloping coastal regions are thought to retreat faster than steeper regions [17].

General Bathymetric Chart of the Oceans (GEBCO) data of 30-arc seconds grid resolution coastal topography and bathymetry has been used to get the regional slope of the coastal area. GEBCO also incorporates land elevations derived from the Global Land One-kilometer Base Elevation project data set. GEBCO data sets are useful in deriving the coastal slope values both on land and in the ocean. 3D analyst tool of ArcGIS 9.3 was used in preparing the coastal slope map. Coastal areas having gentle slope were considered as highly vulnerable areas and areas of steep slope as areas of low vulnerability.

3.4. Regional Elevation. It is important to study the coastal regional elevation detail in the study area to identify and estimate the extent of land area threatened by future sea level rise. These coastal elevation data are also used to estimate the land potentially available for wetland migration in response to sea level rise and the sea level rise impacts on the human built environment [45]. From the coastal vulnerability point of view, coastal regions having high elevation will be considered as less vulnerable areas because they provide more resistance for inundation against the rising sea level, tsunami run-up, and storm surge.

Those coastal regions having low elevation are considered as highly vulnerable areas. In the present study, Shuttle Radar Topography Mission (SRTM) data was used to derive the coastal regional elevation. A zonal statistical analysis was carried out using ArcGIS and elevation in each grid cell was determined and risk rating was awarded.

3.5. Tidal Range. The tidal range is the vertical difference between the highest high tide and the lowest low tide. From the vulnerability point of view, it is an obvious tendency to designate coastal areas of high tidal range as highly vulnerable. This decision is based on the concept that large tidal range is associated with strong tidal currents that influence coastal behavior. For the current study, coastal areas with high tidal range are considered as highly vulnerable and low tidal range as less vulnerable. Previously, studies were carried out at various locations of the study area and the tidal range has been determined $[28,31,37]$. Table 2 lists the details of the studies and the tidal range. This secondary data was also considered for calculations. 
TABLE 3: Mean significant wave height for different talukas as collected from the literatures.

\begin{tabular}{lcr}
\hline Location & Mean significant wave height $(\mathrm{m})$ & Source \\
\hline Karwar, Ankola \& Kumta & 1.6 & Kumar et al. [31] \\
Honnavar & 1.9 & Kumar et al. [31] \\
Kundapur & 1.0 & Shanas and Sanil Kumar [39] \\
Bhatkal & 1.25 & Nayak et al. [40] \\
Udupi (Malpe) & 1.9 & Kumar et al. [31] \\
Mangaluru & 2.0 & Dwarakish et al. [28] \\
\hline
\end{tabular}

3.6. Significant Wave Height. Significant wave height is the average height of the one-third highest waves valid for the indicated 12-hour period. Mean significant wave height is used as a proxy for wave energy that drives coastal sediment transport [46]. The vulnerability study based on wave height is an important step in setting up an all-hazards warning and management system [46].

The movement and transport of coastal sediments are dependent upon the wave energy which varies as the square of the wave height [47]. With increase in the wave height and eventual increase in wave energy, land is lost and coast will witness increased erosion and inundation along the shore. Hence, the coastal areas of high wave height are considered as more vulnerable coasts and areas of low wave height as less vulnerable coasts. In the present study, wave heights in the study area were collected from the various other studies conducted primarily on wave characteristics in the study area. Table 3 shows the details of the data collected.

3.7. Population. Coastal region has high population density compared to upland areas. Population can also be interpreted as a direct "erosion-inducing" variable because the presence of large number of people near the coast may produce damaging impacts on the coastal area [48]. Hence, presence of human habitation increases the vulnerability of the region. In the present study, the population was considered as a pressure exerting factor on the coastal system and hence areas with a higher concentration of people are considered as more susceptible to erosion, similar to Hegde and Reju [18].

Worldpop project provides high resolution and contemporary data on human population distributions for Southeast Asian countries in raster data format. An alpha version data, estimated to match UN population estimate for the year 2015 , was used in the present study. The data set is of raster format, with resolution of $100 \mathrm{~m}$ at the equator. The assemble of the Worldpop spatial data sets principally follows the methodologies outlined by Gaughan et al. [49], Linard et al. [50], Linard et al. [51], and Tatem et al. [52].

3.8. Calculation of CVI. Once each section of coastline is assigned a risk value for each variable, the CVI is calculated as the square root of the product of the ranked variables divided by the total number of variables [17]. The CVI is represented by

$$
\mathrm{CVI}=\sqrt{\frac{a * b * c * d * e * f * g}{7}}
$$

where $a=$ risk rating assigned to sea level change rate, $b=$ risk rating assigned to shoreline change rate, $c=$ risk rating assigned to coastal slope, $d=$ risk rating assigned to coastal regional elevation, $e=$ risk rating assigned to tidal range, $f=$ risk rating assigned to significant wave height, and $g=$ risk rating assigned to population density.

\section{Results and Discussion}

4.1. Relative Sea Level Change Rate. For the available data, it was observed that sea level was falling at a rate of $1.3 \mathrm{~mm}$ per year at the Karwar station while it was rising at a rate of $0.8 \mathrm{~mm}$ per year at the Mangaluru station as shown in Figures 3(a) and 3(b), respectively. Douglas [53] acknowledged that, to determine the trends in long-term sea level changes, ideal record length greater than 60 years is desirable. Since such long duration records were not available for the present study region, the tide gauge data of Cochin (64 years) was also considered to verify the trend of SLR and it was observed that sea level rise was about $1.0 \mathrm{~mm}$ per year.

Unnikrishnan and Shankar [54] estimated that the sea level along the Indian coast has increased at a rate varying between 1.06 and $1.75 \mathrm{~mm}$ per year during the period 1969 to 2007 , depending on the tide gauge recording site, with an estimated regional average of $1.29 \mathrm{~mm}$ per year, subsequent to a global isostatic adjustment correction. The SLR observed at the study area is less in comparison with global average rate of about $1.7 \mathrm{~mm}$ per year [55] and also less than regional average. Hence, the study area is considered to be less vulnerable to sea level rise and lowest ranking of 1 was awarded for the entire coast.

4.2. Coastal Slope. The regional coastal slope was calculated for a distance of $6 \mathrm{~km}(3 \mathrm{~km}$ each from shoreline on sea and landside) perpendicular to the shoreline at an interval of $1.5 \mathrm{~km}$. The five vulnerability classes and the slope range in each class are adopted by Pendleton et al. [56]. A slope greater than $0.6 \%$ is assigned low vulnerability and less than $0.3 \%$ is assigned high vulnerability as shown in Table 4 and accordingly vulnerability ranks (indicating the vulnerability levels in terms of coastal slope) are assigned to all segments of the coast.

4.3. Regional Elevation. The mean regional elevation within study area varied between $0.69 \mathrm{~m}$ in Mangaluru and $78.94 \mathrm{~m}$ in Karwar. An elevation value greater than $40 \mathrm{~m}$ is assigned low vulnerability and less than $10 \mathrm{~m}$ is assigned high vulnerability as shown in Table 4 . The minimum value of $10 \mathrm{~m}$ 


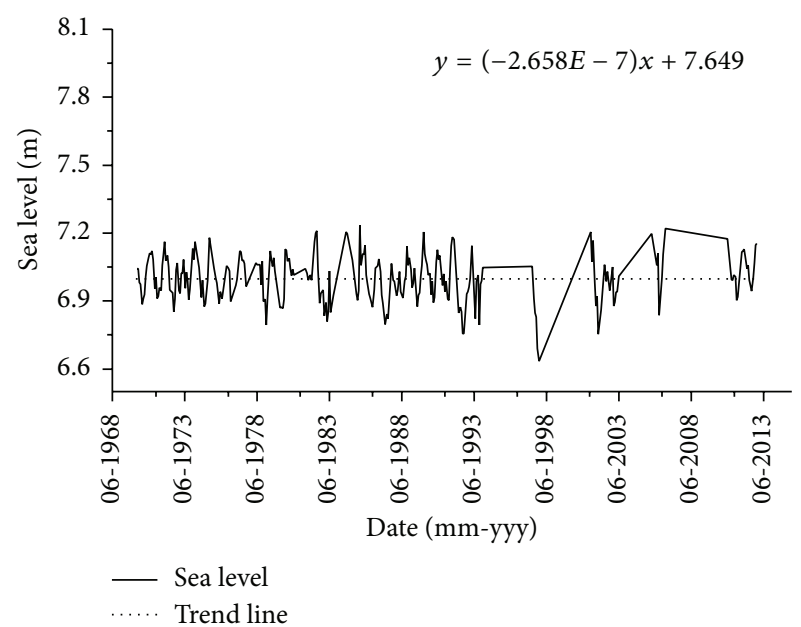

(a)

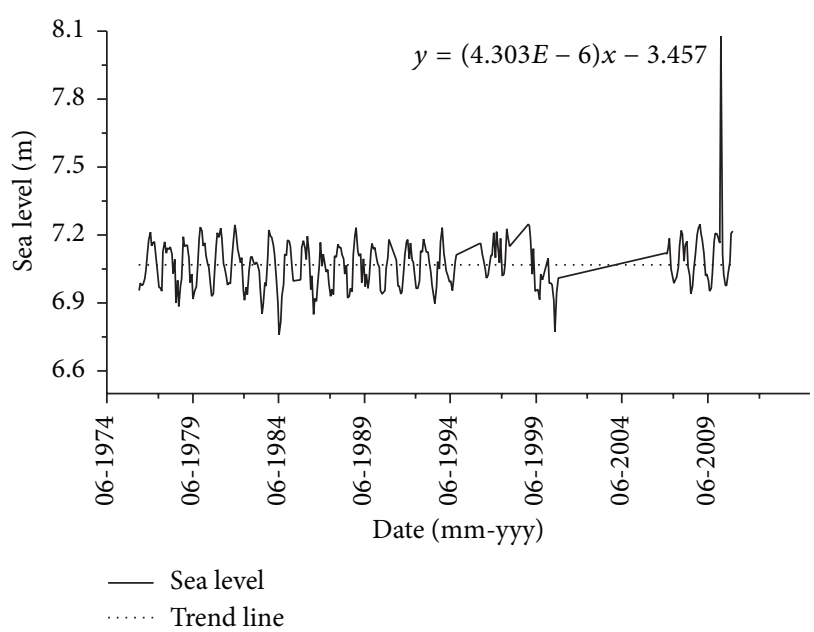

(b)

FIgURE 3: (a) Sea Level variation at Karwar. (b) Sea Level variation at Mangaluru.

TABLE 4: Ranges of variables for vulnerability ranking.

\begin{tabular}{|c|c|c|c|c|c|}
\hline \multirow{2}{*}{ Variable } & \multicolumn{5}{|c|}{ Ranking of vulnerability } \\
\hline & 1 & 2 & 3 & 4 & 5 \\
\hline Coastal slope (\%) & $>0.60$ & $0.5-0.6$ & $0.4-0.5$ & $0.3-0.4$ & $<0.3$ \\
\hline Mean tide range $(\mathrm{m})$ & $<1.0$ & $1.0-2.0$ & $2.0-3.0$ & $3.0-4.0$ & $>4.0$ \\
\hline Regional elevation (m) & $<10$ & $10-20$ & $20-30$ & $30-40$ & $>40$ \\
\hline Shoreline change rate $\left(\mathrm{m}_{\text {year }}{ }^{-1}\right)$ & $>+2.0$ & +1.0 to +2.0 & -1.0 to +1.0 & -2.0 to -1.0 & $<-2.0$ \\
\hline Mean significant wave height $(\mathrm{m})$ & $<0.7$ & $0.7-1.4$ & $1.4-2.1$ & $2.1-2.8$ & $>2.8$ \\
\hline Population (person per $200 \mathrm{~m}^{2}$ ) & $<19$ & $44-20$ & $80-45$ & $326-81$ & $>326$ \\
\hline
\end{tabular}

was considered based on the Indian Ocean earthquake of 26 December 2004 of magnitude 9.0 on the Richter scale which resulted in devastating tsunami along the shores of Indonesia, Sri Lanka, South India, Thailand, and other countries with waves up to $15 \mathrm{~m}$ high.

4.4. Tidal Range. Tidal range is ranked such that microtidal $(<1 \mathrm{~m})$ coasts have very low vulnerability and macrotidal ( $>6 \mathrm{~m}$ ) coasts have a very high vulnerability. The vulnerability ranking given is taken from the vulnerability ranges of Diez et al. [57]. The study area is characterized by mesotidal coasts as the tidal range is within $6 \mathrm{~m}$ but greater than $1 \mathrm{~m}$. Entire study area has fallen into two categories, namely, very low vulnerable level $(<1.0 \mathrm{~m})$ and low vulnerable level $(1.0$ to $2.0 \mathrm{~m}$ ) as far as the tidal range is considered. Accordingly, the entire coast is classified into these two vulnerability categories.

4.5. Significant Wave Height (SWH). Mean SWH in the study area varied between $1.0 \mathrm{~m}$ and $2.0 \mathrm{~m}$. The vulnerability levels were adopted by Dwarakish et al. [28]. Kundapur was having a lowest SWH of $1.0 \mathrm{~m}$ while Mangaluru had highest SWH of $2.0 \mathrm{~m}$. It was assumed that the mean SWH was as per Table 3 within the limits of corresponding talukas.

4.6. Shoreline Change Rate. The shoreline change rate in the study area was calculated for a period of 42 years (1972 to 2014). The Output from DSAS revealed that about $4.09 \mathrm{~km}$

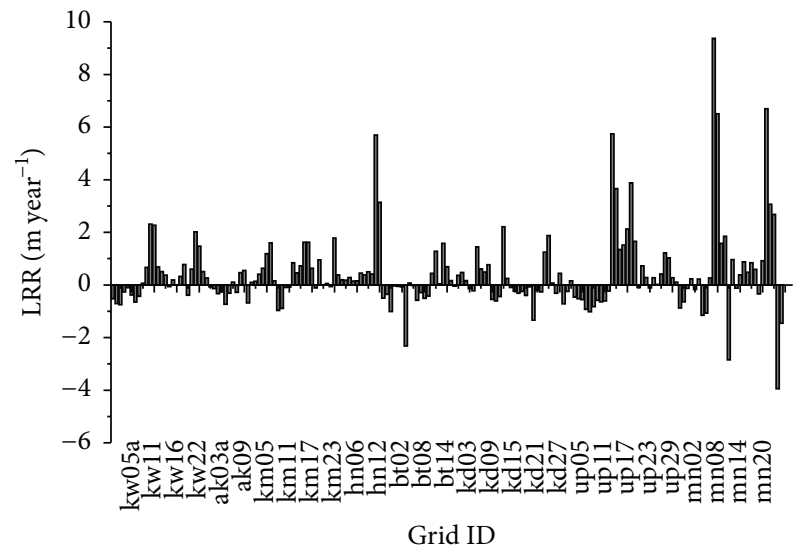

FIGURE 4: Mean shoreline change rate along the grids.

of coastline had a very high risk rating along the coastal stretch of southern Mangaluru. About $14.25 \mathrm{~km}$ of coastline was of high risk rating, along the coastal stretches near southern parts of Mangaluru, Kundapur, and Kumta and also in northern Udupi and Bhatkal. About $267.50 \mathrm{~km}$ of coastline was under a moderate risk while 1.5 and $10.66 \mathrm{~km}$ stretch were under low and very low risk category, respectively. Average accretion for the whole of the study area was found to be $1.133 \mathrm{~m}$ per year and average erosion was $0.533 \mathrm{~m}$ per year. Figure 4 shows the mean shoreline change rate in each grid 

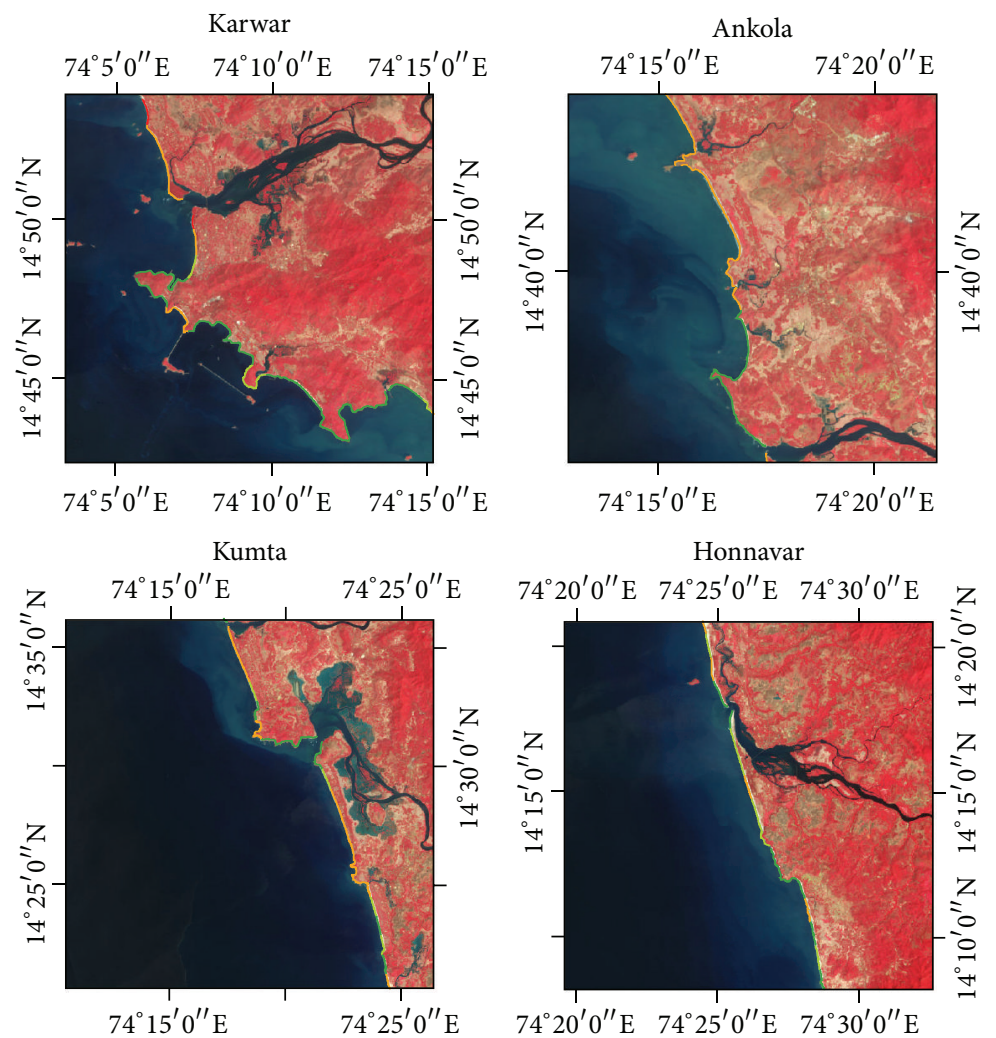

Bhatkal

$74^{\circ} 25^{\prime} 0^{\prime \prime} \mathrm{E} \quad 74^{\circ} 30^{\prime} 0^{\prime \prime} \mathrm{E} \quad 74^{\circ} 35^{\prime} 0^{\prime \prime} \mathrm{E}$

Kundapur

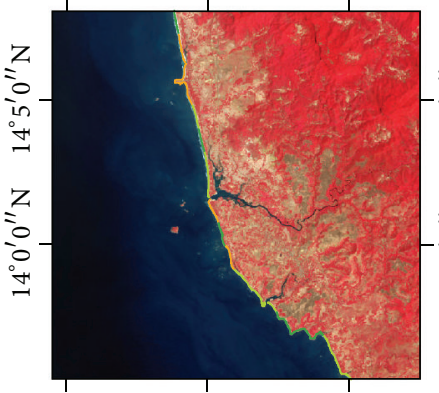

$74^{\circ} 30^{\prime} 0^{\prime \prime} \mathrm{E} \quad 74^{\circ} 40^{\prime} 0^{\prime \prime} \mathrm{E} \quad 74^{\circ} 50^{\prime} 0^{\prime \prime} \mathrm{E}$

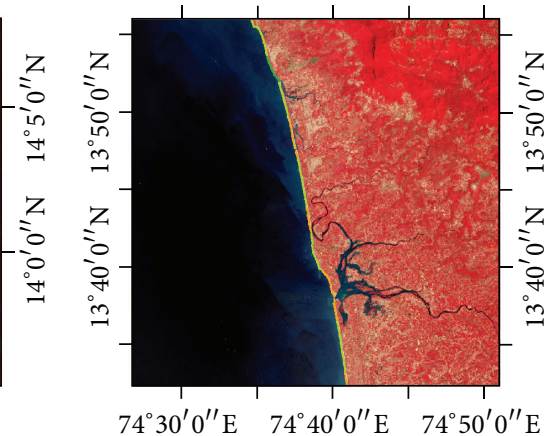

$74^{\circ} 25^{\prime} 0^{\prime \prime} \mathrm{E} \quad 74^{\circ} 30^{\prime} 0^{\prime \prime} \mathrm{E} \quad 74^{\circ} 35^{\prime} 0^{\prime \prime} \mathrm{E}$
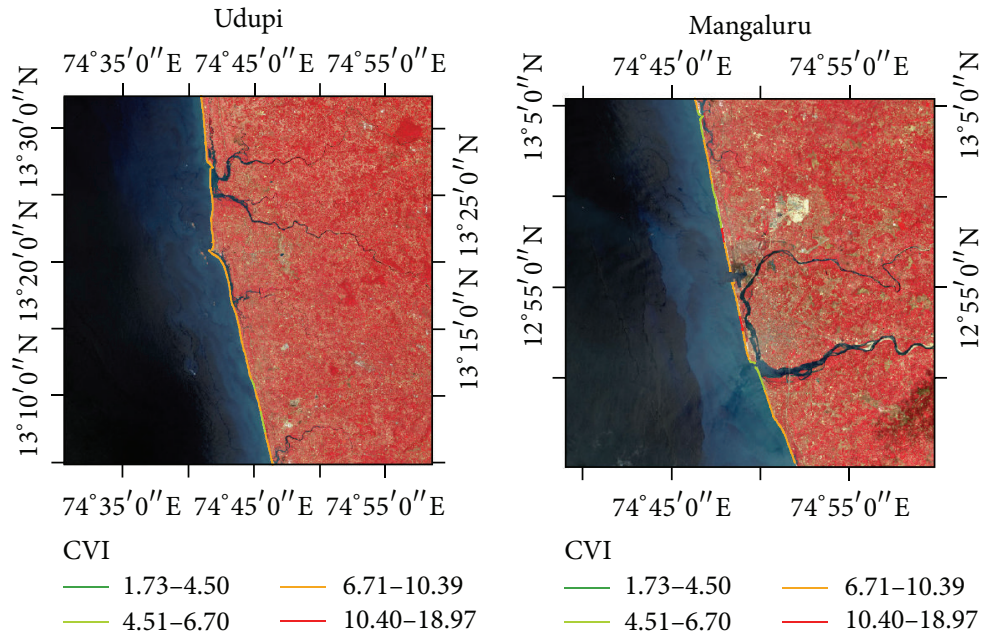

FIgURE 5: CVI for study area. 
TABLE 5: CVI for talukas.

\begin{tabular}{lcccc}
\hline \multirow{2}{*}{ Taluka } & \multicolumn{4}{c}{ CVI } \\
& Max. & Min. & Average & $\sigma$ \\
\hline Karwar & 18.97 & 4.24 & 6.04 & 3.36 \\
Ankola & 9.48 & 3.67 & 6.44 & 2.37 \\
Kumta & 9.48 & 3.67 & 6.28 & 1.87 \\
Honnavar & 7.34 & 3.67 & 5.20 & 1.46 \\
Bhatkal & 7.74 & 1.73 & 5.34 & 1.65 \\
Kundapur & 8.00 & 2.44 & 5.89 & 1.21 \\
Udupi & 9.79 & 6.00 & 7.78 & 2.41 \\
Mangaluru & 15.49 & 4.89 & 7.94 & 0.94 \\
\hline
\end{tabular}

along the study area. The risk ranking was awarded based on the risk category formed by Pendleton et al. [56] and is described in Table 4.

4.7. Population Distribution. Georeferenced population raster downloaded from Worldpop project has data values varying from 0 to 326 persons per $200 \mathrm{~m}^{2}$ for the study area. The population is considered to be a stressor variable in the study. It was assumed that vulnerability varied exponentially with population density, and the data was classified into 5 classes. The zones with values equal to or less than 19 persons per $200 \mathrm{~m}^{2}$ were awarded with least ranking and regions with value equal to or more than a value of 326 persons per $200 \mathrm{~m}^{2}$ were considered as highly vulnerable and highest rank was assigned. Table 4 shows the intermediate values for other classes.

Coastal Vulnerability Index (CVI). Coastal vulnerability index map for the Karnataka Coast is shown in Figure 5. The calculated CVI values range from 1.73 to 18.97 . Table 5 details the CVI for each taluk with statistical parameters. The mean, mode, and median CVI values are 6.52, 7.34, and 6.92, respectively. The standard deviation is 2.21. The CVI scores are divided into low, moderate, high, and very high vulnerability categories based on the quartile ranges [56]. The 25th, 50th, and 75 th percentiles are $4.90,6.92$, and 7.35 , respectively. The lower range of CVI values indicates low risk, followed by moderate risk, high risk, and finally the upper range of values indicating the coastal stretches having very high risk.

The present study is an attempt to categorize the coast of Karnataka according to its coastal vulnerabilities. The variables under consideration are sea level change, coastal slope, regional elevation, tidal range, significant wave height, and population density. A total of $298 \mathrm{~km}$ of shoreline are ranked in the study. About $68.65 \mathrm{~km}$ of the shoreline is very high vulnerable category and $79.26 \mathrm{~km}$ of shoreline is high vulnerable category. Of the remaining shoreline, $59.14 \mathrm{~km}$ and $91.04 \mathrm{~km}$ are of moderate and low vulnerable categories, respectively.

Table 5 shows variation of CVI for each taluka. The coasts of Mangaluru and Udupi fall under high risk category and all other talukas are under moderate risk. The CVI in the present study was primarily influenced by the risk ranking of the shoreline change rate, population, and the coastal slope. It was observed that coasts of Mangaluru, Kumta, and
Bhatkal were under erosion with an average value of 0.21 , 0.13 , and $0.14 \mathrm{~m}$ per year, respectively, while for other talukas accretion was observed. The sensitivity of the CVI to the socioeconomic variable "population" was examined and it was found that CVI significantly decreased in the talukas of Mangaluru, Udupi, and Karwar, on omission of variable and on a relative basis. The coastal slope was observed to be steep in northern talukas, that is, in Karwar, Ankola, and Kumta, while Kundapur, Udupi, and Mangaluru had mild slope topography. This was primarily because in Karwar, Ankola, and Kumta we find the headlands and cliffs very close to the coast and southern talukas have more open beaches.

\section{Conclusion}

In the view of the rising sea levels and other coastal hazards, an assessment of coast for its vulnerability to these threats is necessary in order to take suitable actions to protect the people and property. It was observed that $68.65 \mathrm{~km}$ of the shoreline of the study area was under very high vulnerable category and $79.26 \mathrm{~km}$ of shoreline is high vulnerable category while $59.14 \mathrm{~km}$ and $91.04 \mathrm{~km}$ of coast are of moderate and low vulnerable categories, respectively. Present study also evaluated the transformation of the Karnataka coastline using Landsat satellite images. The CVI developed in the present study provides an understanding about the vulnerability of the Karnataka Coast to erosion, coastal flooding, and relative sea level change and as well as facilitates policy options for coastal planners and authorities with regard to prioritizing coastal areas for mitigation.

\section{Competing Interests}

The present study is a work of pure academic research. The authors declare that there are no competing interests regarding the publication of this paper.

\section{References}

[1] F. L. Alves, C. Coelho, C. D. Coelho, and P. Pinto, "Modelling coastal vulnerabilities: tool for decision support system at intermunicipality level," Journal of Coastal Research, no. 64, pp. 966970, 2011.

[2] R. J. Nicholls and N. Mimura, "Regional issues raised by sealevel rise and their policy implications," Climate Research, vol. 11, no. 1, pp. 5-18, 1999.

[3] IPCC (Intergovernmental Panel on Climate Change), IPCC Report, Working Group-I, Climate Change 2001: The Scientific Basis, Cambridge University Press, Cambridge, UK, 2001, http://www.ipcc.ch/ipccreports/tar/wg1/408.htm.

[4] ICZMP, "Document of world bank-project appraisal document for an integrated coastal zone management project," Report 54612-IN, Integrated Coastal Zone Management, 2010, http://www.sicommoef.in/Data/Sites/1/skins/gec-sicom/ images/docs/pad.pdf.

[5] N. N. V. Sudha Rani, A. N. V. Satyanarayana, and P. K. Bhaskaran, "Coastal vulnerability assessment studies over India: a review," Natural Hazards, vol. 77, no. 1, pp. 405-428, 2015. 
[6] T. S. Kumar, R. S. Mahendra, S. Nayak, K. Radhakrishnan, and K. C. Sahu, "Coastal vulnerability assessment for Orissa State, East Coast of India," Journal of Coastal Research, vol. 26, no. 3, pp. 523-534, 2010.

[7] S. L. Cutter, J. T. Mitchell, and M. S. Scott, "Revealing the vulnerability of people and places: a case study of Georgetown County, South Carolina," Annals of the Association of American Geographers, vol. 90, no. 4, pp. 713-737, 2000.

[8] A. Parthasarathy and U. Natesan, "Coastal vulnerability assessment: a case study on erosion and coastal change along Tuticorin, Gulf of Mannar," Natural Hazards, vol. 75, no. 2, pp. 1713-1729, 2015.

[9] E. R. Thieler and E. S. Hammar-Klose, "National assessment of coastal vulnerability to sea level rise," U.S. Atlantic Coast. U.S. Geological Survey Open-File Report 99-593, 1999.

[10] E. R. Thieler and E. S. Hammer-Klose, National Assessment of Coastal Vulnerability to Sea-Level Rise: Preliminary Results for the U.S. Gulf of Mexico Coast, United States Geological Survey (USGS), Woods Hole, Mass, USA, 2000.

[11] E. R. Thieler and E. S. Hammer-Klose, National Assessment of Coastal Vulnerability to Sea-Level Rise: Preliminary Results for the U.S. Pacific Coast, United States Geological Survey (USGS), Woods Hole, Mass, USA, 2000.

[12] V. M. Gornitz, R. C. Daniel, T. W. White, and K. R. Birdwell, "The development of a coastal risk assessment database: vulnerability to sea-level rise in the U.S. Southeast," Journal of Coastal Research, no. 12, pp. 327-338, 1994.

[13] B. J. Boruff, C. Emrich, and S. L. Cutter, "Erosion hazard vulnerability of US coastal counties," Journal of Coastal Research, vol. 21, no. 5, pp. 932-942, 2005.

[14] G. Ozyurt and A. Ergin, "Application of sea level rise vulnerability assessment model to selected coastal areas of Turkey," Journal of Coastal Research, vol. 1, no. 56, pp. 248-251, 2009.

[15] F. Duriyapong and K. Nakhapakorn, "Coastal vulnerability assessment: a case study of Samut Sakhon coastal zone," Songklanakarin Journal of Science and Technology, vol. 33, no. 4, pp. 469-476, 2011.

[16] V. M. Gornitz, "Vulnerability of the east coast, U.S.A. to future sea level rise," Journal of Coastal Research, vol. 9, pp. 201-237, 1990.

[17] E. A. Pendleton, E. R. Thieler, and S. W. Jeffress, "Coastal vulnerability assessment of golden gate national recreation area to sea level rise," USGS Open-File Report 1058, 2005.

[18] A. V. Hegde and V. R. Reju, "Development of coastal vulnerability index for Mangalore coast, India," Journal of Coastal Research, vol. 23, no. 5, pp. 1106-1111, 2007.

[19] J. R. Jensen and D. L. Toll, "Detecting residential land-use development at the urban fringe," Photogrammetric Engineering \& Remote Sensing, vol. 48, no. 4, pp. 629-643, 1982.

[20] M. El Raey, "Remote sensing of environment," in Proceeding of the 1st Symposium on Environmental Sciences (UNARC '88), Alexandria University, Alexandria, Egypt, April 1988.

[21] G. N. Nayak and P. T. Hanamgond, Encyclopaedia of the World's Coastal Landforms, Springer, New York, NY, USA, 2010.

[22] K. Nageswara Rao, P. Subraelu, T. Venkateswara Rao et al., "Sealevel rise and coastal vulnerability: an assessment of Andhra Pradesh coast, India through remote sensing and GIS," Journal of Coastal Conservation, vol. 12, no. 4, pp. 195-207, 2009.

[23] P. Sheik Mujabar and N. Chandrasekar, "Coastal erosion hazard and vulnerability assessment for southern coastal Tamil Nadu of India by using remote sensing and GIS," Natural Hazards, vol. 69, no. 3, pp. 1295-1314, 2013.
[24] A. A. Kumar and P. D. Kunte, "Coastal vulnerability assessment for Chennai, east coast of India using geospatial techniques," Natural Hazards, vol. 64, no. 1, pp. 853-872, 2012.

[25] A. Jana and A. K. Bhattacharya, "Assessment of coastal erosion vulnerability around Midnapur-Balasore coast, Eastern India using integrated remote sensing and GIS techniques," Journal of the Indian Society of Remote Sensing, vol. 41, no. 3, pp. 675-686, 2013.

[26] P. D. Kunte, N. Jauhari, U. Mehrotra, M. Kotha, A. S. Hursthouse, and A. S. Gagnon, "Multi-hazards coastal vulnerability assessment of Goa, India, using geospatial techniques," Ocean \& Coastal Management, vol. 95, pp. 264-281, 2014.

[27] M. Mahapatra, R. Ramakrishnan, and A. S. Rajawat, "Coastal vulnerability assessment using analytical hierarchical process for South Gujarat coast, India," Natural Hazards, vol. 76, no. 1, pp. 139-159, 2015.

[28] G. S. Dwarakish, S. A. Vinay, U. Natesan et al., "Coastal vulnerability assessment of the future sea level rise in Udupi coastal zone of Karnataka state, west coast of India," Ocean \& Coastal Management, vol. 52, no. 9, pp. 467-478, 2009.

[29] L. R. Appelquist and T. Balstrøm, "Application of a new methodology for coastal multi-hazard-assessment \& management on the state of Karnataka, India," Journal of Environmental Management, vol. 152, 10 pages, 2015.

[30] J. Dattatri, Coastal Erosion and Protection along Karnataka Coast, Centre for Environmental Law, Education, Research and Advocacy (CEERA), The National Law School of India University, 2007.

[31] V. S. Kumar, G. U. Dora, S. Philip, P. Pednekar, and J. Singh, "Variations in tidal constituents along the nearshore waters of Karnataka, West Coast of India," Journal of Coastal Research, vol. 27, no. 5, pp. 824-829, 2011.

[32] S. Nayak, "Role of remote sensing to integrated coastal zone management," in Proceedings of the 20th Congress of the International Society for Photogrammetry and Remote Sensing Commission, vol. 7, p. 18, Istanbul, Turkey, 2004.

[33] P. A. O. Abuodha and C. D. Woodroffe, "Assessing vulnerability to sea-level rise using a coastal sensitivity index: a case study from southeast Australia," Journal of Coastal Conservation, vol. 14, no. 3, pp. 189-205, 2010.

[34] S. B. Mukesh, "Coastal vulnerability, adaptation and risk assessment due to environmental change in Apodi Mossoro estuary, Northeast Brazil," International Journal of Geomatics and Geosciences, vol. 1, no. 3, pp. 620-638, 2010.

[35] R. J. Nicholls, P. P. Wong, V. R. Burkett et al., "Coastal systems and low-lying areas," in Climate Change 2007: Impacts, Adaptation and Vulnerability. Contribution of Working Group II to the Fourth Assessment Report of the Intergovernmental Panel on Climate Change, M. L. Parry, O. F. Canziani, J. P. Palutikof, P. J. van der Linden, and C. E. Hanson, Eds., chapter 6, pp. 315356, Cambridge University Press, Cambridge, UK, 2007.

[36] J. A. Church and J. M. Gregory, Climate Change 2001: Working Group I: The Scientific Basis, chapter 11, International Panel on Climate Change, 2001.

[37] V. S. Kumar, K. C. Pathak, P. Pednekar, N. S. N. Raju, and R. Gowthaman, "Coastal processes along the Indian coastline," Current Science, vol. 91, no. 4, pp. 530-536, 2006.

[38] V. Sanil Kumar, G. Johnson, G. Udhaba Dora, S. P. Chempalayil, J. Singh, and P. Pednekar, "Variations in nearshore waves along Karnataka, west coast of India," Journal of Earth System Science, vol. 121, no. 2, pp. 393-403, 2012. 
[39] P. R. Shanas and V. Sanil Kumar, "Coastal processes and longshore sediment transport along Kundapura coast, central west coast of India," Geomorphology, vol. 214, pp. 436-451, 2014.

[40] S. R. Nayak, V. S. Hegde, G. Shalini et al., "Geomorphic processes in the vicinity of the venkatapur river mouth, central west coast of india: implications for estuarine sedimentation," Journal of Coastal Research, vol. 26, no. 5, pp. 925-934, 2010.

[41] R. J. Savage and E. R. Foster, "Historical shoreline change in southeast Florida," in Coastal Zone '89, O. T. Magoon, H. Converse, D. Miner, L. T. Tobin, and D. Clark, Eds., pp. 44064433, American Society of Civil Engineers, Reston, Va, USA, 1989.

[42] E. R. Thieler, E. A. Himmelstoss, J. L. Zichichi, and T. L. Miller, "Digital Shoreline Analysis System (DSAS) version 3.0: an ArcGIS extension for calculating shoreline change," US Geological Survey Open-File Report 2005-1304, 2005.

[43] M. Crowell and S. P. Leatherman, "Coastal erosion mapping and management," Journal of Coastal Research, vol. 28, pp. 1-196, 1999.

[44] E. R. Thieler, "National assessment of coastal vulnerability to future sea-level rise," USGS Fact Sheet FS-076-00, US Geological Survey, 2000, http://pubs.usgs.gov/.

[45] K. E. Anderson, D. R. Cahoon, B. Guitierrez, and E. R. Thieler, "The physical environment," Public Review Draft, US Climate Change Science Program, Environmental Protection Agency, Washington, DC, USA, 2005.

[46] USGS, “The Digital Shoreline Analysis System (DSAS) version 3.0, an ArcGIS extension for calculating histrionic shoreline change," Open-File Report 2005-1304, 2005, http://woodshole .er.usgs.gov/project-pages/DSAS/version3/.

[47] USGS (U.S. Geological Survey), National Assessment of Coastal Vulnerability to Sea level Rise: Preliminary Results for the U.S. Gulf of Mexico Coast, 2001, http://pubs.usgs.gov/of/2000/of00179/pages/risk.html.

[48] S. McLaughlin, J. McKenna, and J. A. G. Cooper, "Socioeconomic data in coastal vulnerability indices: constraints and opportunities," Journal of Coastal Research, vol. 36, pp. 487-497, 2002.

[49] A. E. Gaughan, F. R. Stevens, C. Linard, P. Jia, and A. J. Tatem, "High resolution population distribution maps for Southeast Asia in 2010 and 2015," PLoS ONE, vol. 8, no. 2, Article ID e55882, 2013.

[50] C. Linard, M. Gilbert, R. W. Snow, A. M. Noor, and A. J. Tatem, "Population distribution, settlement patterns and accessibility across Africa in 2010," PLoS ONE, vol. 7, no. 2, Article ID e31743, 2012.

[51] C. Linard, V. A. Alegana, A. M. Noor, R. W. Snow, and A. J. Tatem, "A high resolution spatial population database of Somalia for disease risk mapping," International Journal of Health Geographics, vol. 9, article 45, 2010.

[52] A. J. Tatem, A. M. Noor, C. von Hagen, A. Di Gregorio, and S. I. Hay, "High resolution population maps for low income nations: combining land cover and census in East Africa," PLoS ONE, vol. 2, no. 12, Article ID e1298, 2007.

[53] B. C. Douglas, "Sea level change in the era of the recording tidegauge, in Sea Level Rise," in International Geophysical Service, B. C. Douglas, M. S. Kearney, and S. P. Leatherman, Eds., vol. 75, pp. 37-64, Elsevier, New York, NY, USA, 2001.

[54] A. S. Unnikrishnan and D. Shankar, "Are sea-level-rise trends along the coasts of the north Indian Ocean consistent with global estimates?" Global and Planetary Change, vol. 57, no. 3-4, pp. 301-307, 2007.
[55] J. A. Church and N. J. White, "A 20th century acceleration in global sea level rise," Geophysical Research Letters, vol. 33, no. 1, 2006.

[56] E. A. Pendleton, S. J. Williams, and E. R. Thieler, "Coastal vulnerability assessment of assateague island national seashore (ASIS) to sea-level rise," U.S. Geological Survey, Open-File Report 2004-1020, 2004.

[57] P. G. Diez, G. M. E. Perillo, and M. C. Piccolo, "Vulnerability to sea-level rise on the coast of the Buenos Aires province," Journal of Coastal Research, vol. 23, no. 1, pp. 119-142, 2007. 


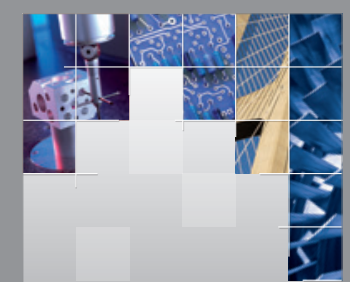

\section{Enfincering}
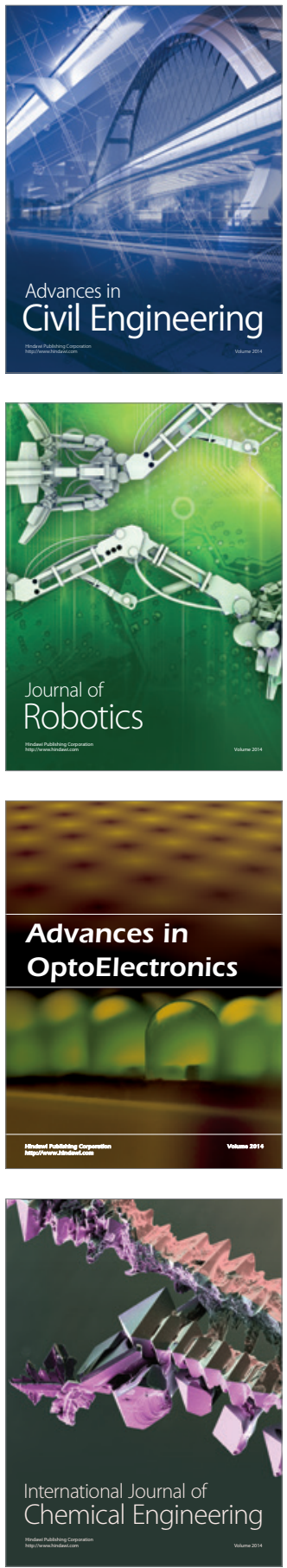

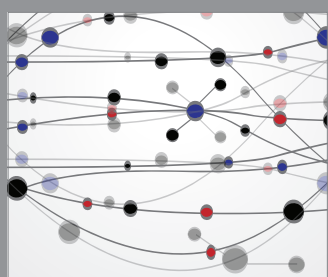

The Scientific World Journal

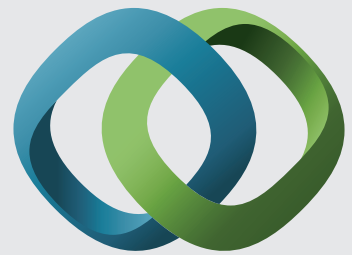

\section{Hindawi}

Submit your manuscripts at

http://www.hindawi.com
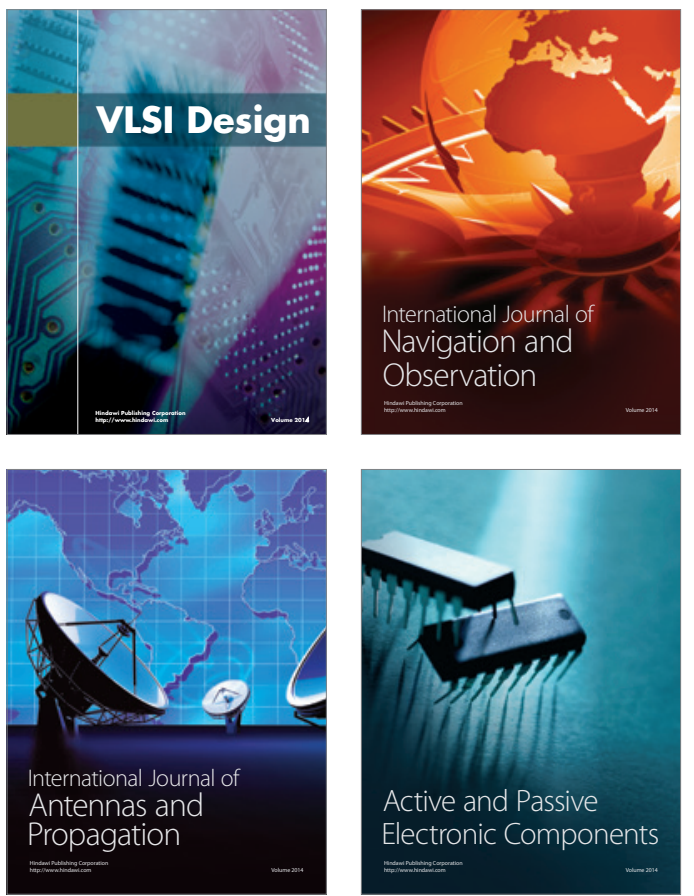
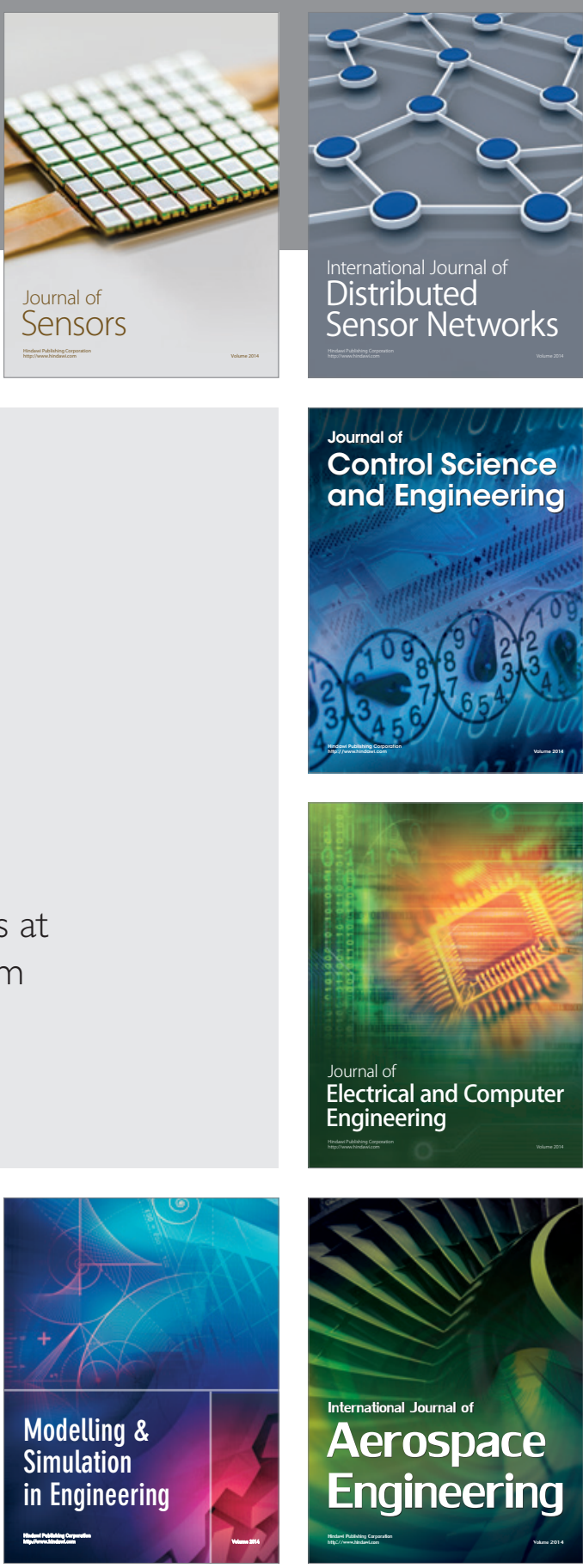

International Journal of

Distributed

Sensor Networks

Journal of

Control Science

and Engineering
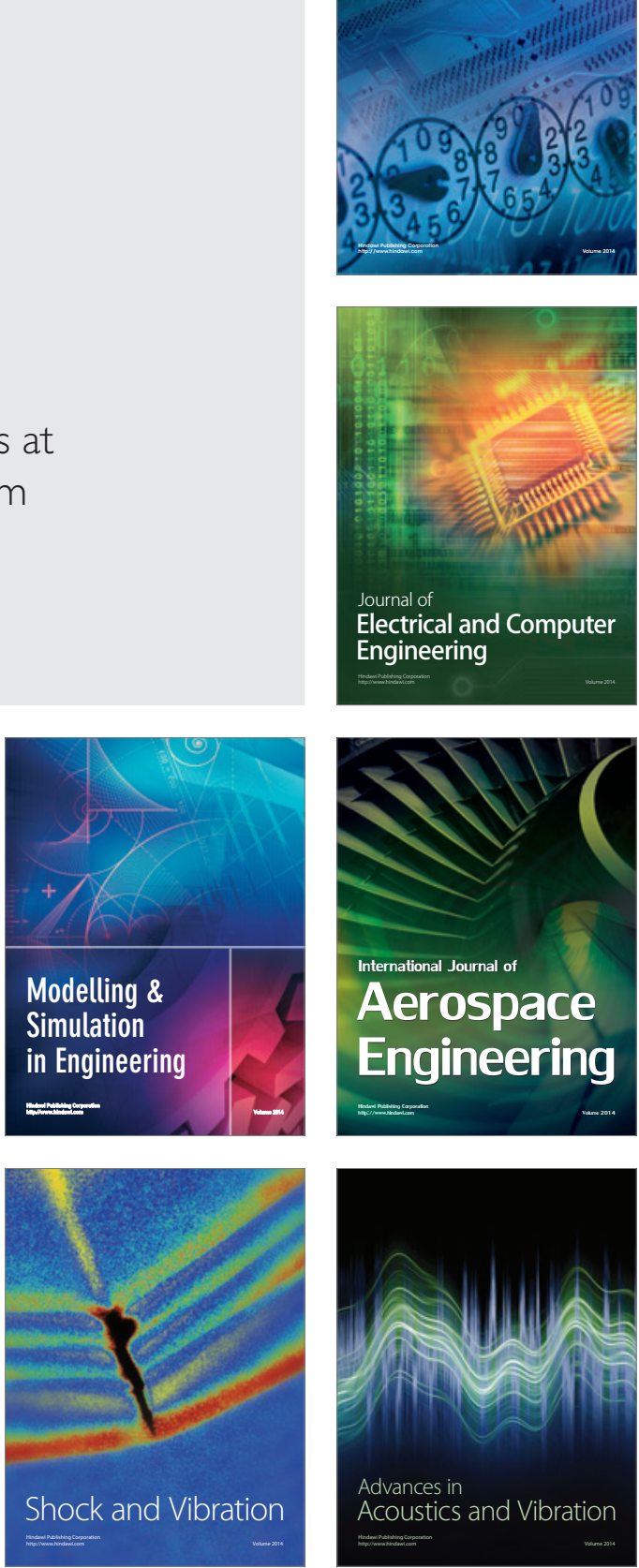